\title{
GORRESPONDENCE
}

To the Editor,

Journal of African Law.

Sir,

\section{THE OMBUDSMAN IN AFRICA}

Professor Mittlebeeler ([1965] J.A.L. 184) has made an interesting critique of the feasibility of an ombudsman in African one-party states, and has pointed out the very real difficulty facing such an officer when he is backed by a weak or non-existent Parliament. That is, however, not the end of the matter.

In the two countries which originated the ombudsman, Sweden and Finland, that office was an extension by Parliament of a preexisting post: Chancellor of Justice (fustitiekansler or JK). The JK also had the task of supervising the administration and causing illegal action by public officials to be reprehended. But he was appointed by the Crown and was a high officer of state. Because the Swedish Parliament did not trust the Crown in 1809 , it introduced its own ombudsman (Justitieombudsman or JO) to do the same work of supervision, but to report to Parliament and not the King and thus to be more independent of royal pressure. As a result, today the two officers, JK and JO, are both carrying out the same task in the same way and doing so equally successfully from the citizens' point of view. There is no evident demarcation between them and cases seem to be referred by the public rather haphazardly to one or to the other. Close personal co-operation between them prevents any wasteful overlapping in practice. In Sweden the JO appears to have slightly greater prestige with public and press, but not so in Finland. The JK continued to exist after Finland was transferred from Sweden to Russia in 1809 (albeit under the name of Procurator) and a JO was not appointed until 1919 when Finland first became independent. By then, the $\mathrm{JK}$ was carrying out his protective rôle perfectly adequately and he has therefore still retained the greater prestige over the JO, although again the two officers largely overlap in their functions.

The remarks by Professor Mittlebeeler in his fourth paragraph are, therefore, only part of the truth. Satisfactory control of the administration in Sweden and Finland is maintained by an officer who is indeed an "arm of the executive" and has something akin to ministerial status (at least in Finland). The originating idea was that the King wished to ensure for his subjects a just and legal administration by his servants ( $c f$. the French Conseil d'État). There is no reason why an autocratic African ruling body (whether it be a sole party, a military oligarchy or a Parliamentary cabinet) should not share this desire for just administration with autocratic European monarchs. Of course, unless it wishes the administration to be subject to rules of law in its conduct, neither JO nor JK will be of any use. But if it does so wish, then it is a matter of constitutional 
expediency which officer is the more suitable: a weak Parliament points to a Chancellor of Justice, a strong Parliament to an Ombudsman of Justice. In both cases, the officer will have been appointed to ensure that the administration acts according to law, and the rest will be up to him, taking account of the balance of power in the state and the growth of the importance of public opinion. The important thing above all is to have an officer whose sole task this is and who is himself learned, just, diplomatic and incorruptible.

Yours faithfully,

N. March HunNings,

Barrister-at-Law, 20 Queen's Gate, London, S.W.I 